Al-Madrasah: Jurnal Ilmiah Pendidikan Madrasah Ibtidaiyah

Vol. 5, No. 2, 2021

DOI 10.35931/am.v5i2.500

P-ISSN: 2620-5807; E-ISSN: 2620-7184

\title{
PEMBELAJARAN MEMBACA TEKS DRAMA DENGAN MENGGUNAKAN METODE QUANTUM DI KELAS 5 MIN 6 PIDIE
}

\author{
T. Nurullah* ${ }^{1}$, Aninditya Sri Nugraheni $*^{2}$ \\ ${ }^{1}$.Magister PGMI Universitas Islam Negeri Sunan Kalijaga Yogyakarta \\ 2 .Dosen Magister PGMI Universitas Islam Negeri Sunan Kalijaga Yogyakarta \\ Email: *119204080050@student.uin-suka.ac.id *2aninditya.nugraheni@uin- \\ $\underline{\text { suka.ac.id }}$
}

\begin{abstract}
ABSTRAK
Pembelajaran membaca teks drama sangat penting diajarkan di madrasah Karena dapat meningkatkan kemampuan berbahasa, gaya, notasi siswa pada saat bercerita. Penelitian ini bertujuan untuk mengetahui peningkatan penggunaan metode quantum pada saat pembelajaran membaca teks drama dikelas 5 MIN 6 Pidie pada semester II tahun pembelajaran 2020/2021. Jenis penelitian yang digunakan yaitu penelitian deskriptif dengan bentuk penelitian kualitatif dan prosedur pada penelitian ini menggunakan penelitian tindakan kelas (PTK) yang dilakukan sebanyak 2 siklus. Data yang diperoleh dari penelitian ini merupakan proses pembelajaran membaca teks drama menggunakan metode quantum mengalami meningkat dengan hasil yang dicapai pada siklus I pada Jumat 8 Januari 2021 yaitu dengan nilai rata-rata 74.2 yang diikuti oleh 20 siswa yang hadir 83.33\%, sedangkan pada siklus II pada Senin 12 Januari 2021 meningkat dengan nilai rata-rata menjadi 76.17 yang diikuti oleh 23 siswa yang hadir 95.83\%. Adapun siswa yang tidak hadir pada siklus I sebanyak 4 dengan presentase 16.66 sedangkan siswa yang tidak hadir pada siklus ke II sebanyak 1 siswa dengan presentase 4.16\%, Dengan demikian penelitian menggunakan metode quantum sangat penting dalam pembelajaran ini karena dapat meningkatkan pembelajaran siswa.
\end{abstract}

Kata kunci: Pembelajaran Membaca Teks Drama, Metode Quantum 
T. Nurullah, Aninditya Sri Nugraheni : Pembelajaran Membaca Teks Drama Dengan Menggunakan Metode Quantum di Kelas 5 MIN Pidie

\section{A. PENDAHULUAN}

Belajar mengajar merupakan suatu proses yang mengandung serangkaian antara guru dan siswa yang memiliki hubungan timbal balik pada berlangsungnya situasi edukatif untuk mencapai tujuan tertentu, tolak ukur utama dalam proses belajar mengajar dengan meningkatkan kualitas pendidikan. ${ }^{1}$

Peserta didik membutuhkan pembelajaran yang mudah dipelajari dan difahami sehingga peserta didik mampu dalam menaggapi segala pembelajaran yang diajarkan oleh gurunya, ${ }^{2}$ karena dengan begitu mampu membawa perubahan pada individu sipelajar untuk memperoleh sebuah perubahan perilaku yang baru, baik perubahan afektif, kognitif dan psikomotor bagi sianak. ${ }^{3}$

Guru yang berperan sebagai fasilitator semestinya mampu menguasai segala bidang kebutuhan dalam proses pembelajaran yang akan berlangsung agar terlaksananya suatu pembelajaran yang efektif dan efisien, sehingga siswa tidak bosan dengan segala pembelajaran yang diajarkan. ${ }^{4}$ Adapun yang semestinya dikuasai oleh guru untuk meningkatkan hasil pembelajaran yaitu berupa RPP, Media Pembelajaran, Model Pembelajaran, maupun Metode yang sesuai dengan materi. ${ }^{5}$

\footnotetext{
${ }^{1}$ Esti Priatiningsih, "Peningkatan Keterampilan Membaca Teks Melalui Metode Bermain Peran Di Kelas Ii Sekolah Dasar Negeri Jatisawit 02 Kecamatan Bumiayu Kabupaten Brebes Tahun Pelajaran 2020/2021," MAJALAH LONTAR 32, no. 2 (28 November 2020): 36-48, https://doi.org/10.26877/ltr.v32i2.7294.

${ }^{2}$ Prayogi Nurfauzan, "Pengaruh Model Quantum Learning Terhadap Penguasaan Teknik Dasar Lompat Jauh Siswa Pada Pembelajaran Atletik Di Sekolah Dasar," JMIE (Journal of Madrasah Ibtidaiyah Education) 2, no. 2 (30 November 2018): 254-64, https://doi.org/10.32934/jmie.v2i2.77. 2012), h.49.

${ }^{3}$ Isjoni, Cooperative Learning: Efektifitas Pembelajaran Kelompok (Bandung: Alfabeta, Januari

4 "penilaian metode quantum dalam membaca teks - Penelusuran Google," diakses 17 https://www.google.com/search?q=penilaian+metode+quantum+dalam+membaca+teks\&oq=penil aian+metode+quantum+dalam+membaca+teks\&aqs=chrome..69i57.20463j1j7\&sourceid=chrome \&ie $=$ UTF- 8 .

${ }^{5}$ Khanza Savitra, “12 Peran Guru Dalam Proses Pembelajaran,” DosenPsikologi.com, 13 September 2017, https://dosenpsikologi.com/peran-guru-dalam-proses-pembelajaran.
}

Al-Madrasah: Jurnal Ilmiah Pendidikan Madrasah Ibtidaiyah Vol. 5, No. 2, Januari-Juni 2021 
T. Nurullah, Aninditya Sri Nugraheni : Pembelajaran Membaca Teks Drama Dengan Menggunakan Metode Quantum di Kelas 5 MIN Pidie

Metode pembelajaran berfungsi pula sebagai pedoman bagi para perancang pembelajaran dan para guru dalam merencanakan aktivitas belajar mengajar dan landasan memudahkan dalam penyampaian materi yang rumit menjadi lebih mudah kepada peserta didik, metode harus dapat difahami oleh guru untuk meningkatkan hasil pembelajaran secara efektif ${ }^{6}$ oleh karena itu dengan menggunakan metode pembelajaran peserta didik diharapkan akan lebih mudah memahami segala materi pada saat proses belajar mengajar dan melalui metode pembelajaran guru dapat membantu peserta didik mendapatkan informasi, ide, keterampilan, cara berpikir, dan mengekspresikan ide peserta didik. ${ }^{7}$

Guru harus menentukan kesesuaian pada proses pembelajaran yang dibutuhkan oleh siswa dengan metode yang sangat tepat ${ }^{8}$, maka guru perlu memerhatikan relevansi yang tepat sebelum menggunakan metode pembelajaran yang akan digunakan, adapun yang harus dipertimbangkan oleh guru yaitu: 1). Mempertimbangkan terhadap tujuan yang dicapai dalam pembelajaran 2). Mempertimbangkan hubungan dengan segala materi ajar 3). Mempertimbangkan dari segala sudut peserta didik dan pertimbangan lain yang bersifat nonteknis. ${ }^{9}$

Metode pembelajaran memiliki beberapa model diantaranya sebagai berikut: Metode Quantum, Ceramah, PBL, Inquiri, Jigsaw ${ }^{10}$, adapun penggunaan salah satu metode yang dapat digunakan peneliti yang berhubungan dengan materi pembelajaran membaca teks drama yaitu metode Quantum learning metode

${ }_{7}^{6}$ Isjoni, Cooperative Learning: Efektifitas Pembelajaran Kelompok, h.45.

7 Satrio Wicaksono Sudarman dan Ira Vahlia, "Efektifitas Penggunaan Metode Pembelajaran Quantum Learning Terhadap Kemampuan Pemahaman Konsep Matematis Mahasiswa," Al-Jabar: Jurnal Pendidikan Matematika 7, no. 2 (20 Desember 2016): 275-82, https://doi.org/10.24042/ajpm.v7i2.42.

${ }^{8}$ Darna Safitri, Laurensius Salem, dan Deden Ramdani, "Peningkatan Keterampilan Membaca Teks Drama Menggunakan Metode Jigsaw Di Smp," Jurnal Pendidikan Dan Pembelajaran Khatulistiwa 4, no. 11 (16 November 2015), https://jurnal.untan.ac.id/index.php/jpdpb/article/view/12390.

9 Nadea Zulfa Khairunnosa dan R Rachmy Diana, "Pengaruh Pelatihan Quantum Learning Terhadap Minat Belajar Ilmu Pengetahuan Alam Pada Siswa Sekolah Dasar," Jurnal Intervensi Psikologi (JIP) 10, no. 2 (25 Desember 2018): 73-82, https://doi.org/10.20885/intervensipsikologi.vol10.iss2.art1.

${ }^{10}$ Ina, "20 Macam Macam Metode Pembelajaran Lengkap,” DosenPsikologi.com, 7 Juli 2017.

Al-Madrasah: Jurnal Ilmiah Pendidikan Madrasah Ibtidaiyah Vol. 5, No. 2, Januari-Juni 2021 
T. Nurullah, Aninditya Sri Nugraheni : Pembelajaran Membaca Teks Drama Dengan Menggunakan Metode Quantum di Kelas 5 MIN Pidie

tersebut dapat digunakan oleh pendidik kepada peserta didiknya untuk meningkatkan pengetahuan dan menciptakan pembelajaran efektif, aktif yang nyaman lagi menggairahkan. ${ }^{11}$

Metode quantum merupakan pendekatan pengubahan bermacam-macam yang dilakukan dengan cara interaksi yang ada didalam maupun disekitar situasi belajar. ${ }^{12}$ Interaksi komponen pendidikan akan mengubah kemampuan dan bakatbakat alamiah yang terdapat pada siswa menjadi kesuksesan dalam belajar siswa baik bagi dirinya sendiri maupun lingkunganya. ${ }^{13}$

Ada beberapa hal yang menjadi penilaian utama dalam membaca teks drama dengan metode quantum, Hal tersebut berupa kelancaran, ketepatan intonasi, kejelasan volume suara, kejelasan artikulasi, ketepatan penjedaan, kesesuaian dalam ekspresi.

\section{B. METODE PENELITIAN}

Penelitian ini menggunakan pendekatan kualitatif model penelitian deskriptif kualitatif yang didefinisikan sebagai pendekatan yang digunakan untuk melakukan langkah-langkah representasi obyektif tentang permasalahan dan gejala yang akan diselidiki. Rancangan dalam penelitian ini dengan menggunakan penelitian tindakan kelas (PTK). Teknik pengumpulan data yang digunakan dengan cara menggunakan angket, wawancara, dan observasi untuk menganalisi pembelajaran. Ada 24 Subjek penelitian yang dipilih oleh peneliti yang yaitu siswa pada kelas 5 Min 6 Pidie yang dikaitkan dengan pembelajaran membaca teks drama dengan menggunakan motode quantum learning.

\section{HASIL PENELITIAN DAN PEMBAHASAN}

a. Hasil Penelitian

11 Sudarman dan Vahlia, "Efektifitas Penggunaan Metode Pembelajaran Quantum Learning Terhadap Kemampuan Pemahaman Konsep Matematis Mahasiswa."

12 Imas Nenden Kuraesin, Nana Suryana, dan Nita Anjung Munggaran, "Meningkatkan Minat Baca Peserta Didik Melalui Metode Quantum Reading Dalam Mata Pelajaran Bahasa Indonesia," Madrosatuna : Jurnal Pendidikan Guru Madrasah Ibtidaiyah 2, no. 1 (4 Juli 2019): 42-50, https://doi.org/10.47971/mjpgmi.v2i1.65.

13 Bobbi DePorter, Quantum Learning : Membiasakan Belajar Nyaman Dan Menyenangkan (Kaifa, 2005).

Al-Madrasah: Jurnal Ilmiah Pendidikan Madrasah Ibtidaiyah Vol. 5, No. 2, Januari-Juni 2021 
T. Nurullah, Aninditya Sri Nugraheni : Pembelajaran Membaca Teks Drama Dengan Menggunakan Metode Quantum di Kelas 5 MIN Pidie

Hasil penelitian untuk mengetahui membaca teks drama dengan metode quantum sangat menarik perhatian bagi siswa, siswa terlihat lebih aktif dan agresif ketika membacakan teks drama, masing-masing siklus menggunakan 1 teks drama, adapun teks drama pada siklus 1 berjudul drama tentang 5 orang menyontek, sedangkan pada siklus 2 temanya berjudul Drama tentang persahabatan

indikator penilaian yang peneliti gunakan untuk mengetahui sejauh mana penilaian membaca teks drama yaitu meliputi aspek: 1) Kelancaran, 2) Inotasi/vokal, 3) Ketepatan penjedaan, 4). Gaya/ekspresi, 5). Penguasaan karakter, 6). Penguasaan panggung peneliti menilai siswa sesuai dengan Kriteria Ketuntasan Minimal (KKM) yang telah di tetapkan oleh guru kelas, Adapun Kriteria Ketuntasan Minimal (KKM) pada kelas 5 yaitu sebanyak 65.

Penilaian yang mengikuti KKM yang telah di tentukan akan menghasilkan nilai yang sesuai dengan karakter Predikat, untuk menentukan kriteria penilaian yang tepat bagi peserta didik yaitu dengan cara sebagai berikut

Nilai total - Nilai KKM $=$ Hasil atau $100-65=35$

Hasil 35 yang diperoleh tersebut dibagi menjadi 3 bagian, 1). Bagian pertama 10 rentang untuk predikat $A, 2$ ). Bagian kedua nilai 12 rentang untuk predikat $\mathrm{B}, 3$ ). Bagian ketiga nilai 13 rentang untuk predikat $\mathrm{C}$, Jadi total semuanya adalah $11+12+12=35$.

Tabel 1: Kriteria Penilaian Sesuai dengan Ketentuan Sekolah

\begin{tabular}{|c|c|c|c|c|}
\hline No & Perumusan nilai & Rentang nilai & Predikat & Kategori \\
\hline 1 & $100-10=90$ & $90-100$ & A & Baik sekali \\
\hline 2 & $90-12=78$ & $78-89$ & B & Baik \\
\hline 3 & $78-13=65$ & $65-77$ & C & Sedang/Cukup \\
\hline 4 & $65-15=50$ & $50-64$ & D & Kurang \\
\hline 5 & 50 & $0-49$ & E & Sangat Kurang \\
\hline
\end{tabular}


T. Nurullah, Aninditya Sri Nugraheni : Pembelajaran Membaca Teks Drama Dengan Menggunakan Metode Quantum di Kelas 5 MIN Pidie

Hasil penelitian tindakan kelas yang peneliti rancang dan peneliti laksanakan bersama dengan guru bernama Ibu Mutia S.Pd.I, dengan subjek ialah siswa kelas 5 MIN 6 Pidie yang berjumlah sebanyak 24 siswa pada semester II tahun pembelajaran 2020-2021, yang dilaksanakan sebanyak 2 siklus

Berdasarkan nilai yang diperoleh dari hasil penelitian terhadap kelas 5 MIN 6 Pidie pada siklus 1 yang dilaksanakan pada Jum'at, 08 Januari 2021diikuti oleh 20 siswa sehingga kehadiran siswa mencapai 83.33\%, begitu juga siswa yang tidak dapat hadir sebanyak 4 siswa, sehingga ketidak hadiran siswa mencapai $16.66 \%$. adapun hasil penelitian tindakan kelas sebagai berikut:

Tabel 2 : Hasil Nilai Pembelajaran Membaca Teks Drama Siklus 1

\begin{tabular}{|c|c|c|c|c|c|c|}
\hline No & Kategori & Rentang Nilai & Frekuensi & Bobot & Presentase & \multirow{2}{*}{$\begin{array}{c}\text { Nilai Rata-rata } \\
\text { kelas }\end{array}$} \\
\hline 1 & Roik Sokgli & $90-100$ & - & - & $0 \%$ & \\
\hline 2 & Baik & $78-89$ & 6 & 478 & $35 \%$ & \multirow{5}{*}{$\begin{array}{c}\frac{1484}{2000} \times 100= \\
74.2\end{array}$} \\
\hline 3 & Sedang/Cukup & $65-77$ & 10 & 773 & $45 \%$ & \\
\hline 4 & Kurano & $50-64$ & 4 & 233 & $20 \%$ & \\
\hline 5 & Son $K_{5}$ & 0,40 & & & & \\
\hline & Sangat Kurang & $0-49$ & - & & & \\
\hline \multirow{2}{*}{\multicolumn{2}{|c|}{ Jumlah }} & & 20 & 1484 & $100 \%$ & 74.2 \\
\hline & & & & & & Sedang/Cukup \\
\hline
\end{tabular}

Data yang diperoleh pada tabel 1 menunjukkan bahwa pembelajaran membaca teks drama pada kelas 5 sudah memasuki kategori Sedang/Cukup, hal tersebut dibuktikan dengan nilai rata-rata kelas mencapai 74.2.

Pada data tabel terlihat jelas kemampuan siswa dalam pembelajaran membaca teks drama pada rentang nilai 90 - 100 pada kategori baik sekali belum muncul dengan presentase $0 \%$, adapun penilaian siswa pada rentang nilai $78-89$ pada kategori Baik sudah muncul sebanyak 6 siswa dengan presentase 35\%, sedangkan penilaian siswa pada rentang nilai $65-77$ pada kategori sedang/cukup terdapat 10 siswa dengan persentase $45 \%$, adapun siswa dengan rentang nilai $50-$ 
T. Nurullah, Aninditya Sri Nugraheni : Pembelajaran Membaca Teks Drama Dengan Menggunakan Metode Quantum di Kelas 5 MIN Pidie

64 pada kategori kurang terdapat 4 siswa dengan presentase 20\%, sedangkan siswa pada rentang nilai $0-49$ dengan kategori sangat kurang tidak ditemukan oleh peneliti maupun guru kelas.

Perolehan data tersebut menunjukkan bahwa siswa dalam pembelajaran membaca teks drama sudah banyak yang mencapai penilaian KKM yang diterapkan, Hal ini dilihat dari hasil penelitian siklus 1 terdapat 16 siswa yang mencapai KKM akan tetapi, ada 20\% siswa belum mencapai KKM dan banyak pula siswa hanya mampu mencapai nilai target dengan kriteria cukup saja.

Hasil pembelajaran siswa tersebut menunjukkan peningkatan pembelajaran membaca teks drama dengan menggunakan metode Quantum, walaupun peningkatan pembelajaran menggunakan metode belum terlalu maksimal, karena metode tersebut baru digunakan pada siswa

Berdasarkan nilai yang diperoleh dari hasil penelitian pada siklus 1, maka penelitian dilanjutkan dengan siklus ke 2 terhadap kelas 5 MIN 6 Pidie. Pada siklus ke 2 yang dilaksanakan pada Senin, 12 Januari 2021 yang diikuti oleh 23 siswa maka kehadiran siswa mulai meningkat menjadi 95.83\%, begitu juga siswa yang tidak dapat hadir sebanyak 1 siswa, sehingga ketidak hadiran siswa mencapai $4.16 \%$. adapun hasil penelitian tindakan kelas pada siklus ke 2 sebagai berikut:

Tabel 3 : Hasil Nilai Pembelajaran Membaca Teks Drama Siklus 2

\begin{tabular}{|c|c|c|c|c|c|c|}
\hline No & Kategori & Rentang Nilai & Frekuensi & Bobot & Presentase & \multirow{2}{*}{$\begin{array}{l}\text { Nilai Rata- } \\
\text { rata }\end{array}$} \\
\hline 1 & Baik Sekali & $90-100$ & 3 & 272 & $13 \%$ & \\
\hline 2 & Baik & $78-89$ & 10 & 811 & $43.5 \%$ & \multirow{4}{*}{$\begin{array}{c}\frac{1752}{2300} \times 100= \\
76.17\end{array}$} \\
\hline 3 & Sedang/Cukup & $65-77$ & 8 & 544 & $34.8 \%$ & \\
\hline 4 & Kurang & $50-64$ & 2 & 125 & $8.7 \%$ & \\
\hline 5 & Sangat Kurang & $0-49$ & - & - & - & \\
\hline \multirow{2}{*}{\multicolumn{2}{|c|}{ Jumlah }} & & 23 & 1752 & $100 \%$ & 76.17 \\
\hline & & & & & & Sedang/cukup \\
\hline
\end{tabular}


T. Nurullah, Aninditya Sri Nugraheni : Pembelajaran Membaca Teks Drama Dengan Menggunakan Metode Quantum di Kelas 5 MIN Pidie

Data yang diperoleh pada tabel 2 menunjukkan bahwa pembelajaran membaca teks drama pada kelas 5 berada pada kategori Sedang/Cukup dan mengalami peningkatan dalam belajar, hal tersebut dibuktikan dengan nilai ratarata kelas mencapai 76.17 yang awalnya nilai rata-rata tersebut sebanyak 74.2.

Pada data tabel terlihat jelas kemampuan siswa dalam pembelajaran membaca teks drama pada rentang nilai 90 - 100 pada kategori baik sekali sudah meningkat menjadi 3 siswa dengan presentase 13\%, adapun penilaian siswa pada rentang nilai 78 - 89 pada kategori Baik sudah bertambah 4 siswa hingga menjadi 10 siswa dengan presentase $43.5 \%$, sedangkan penilaian siswa pada rentang nilai 65 - 77 pada kategori sedang/cukup sudah berkurang 2 siswa menjadi 8 siswa dengan persentase $34.8 \%$, adapun siswa dengan rentang nilai 50 - 64 pada kategori kurang sudah berkurang 2 siswa menjadi 2 siswa dengan presentase $8.7 \%$, sedangkan siswa pada rentang nilai $0-49$ dengan kategori sangat kurang tidak ditemukan oleh peneliti maupun guru kelas pada siklus ke2.

Berdasarkan dari hasil pembelajaran siklus ke2 bahwa siswa sudah mencapai peningkatan dalam pembelajaran, Oleh karena itu siswa sudah dikatakan mampu meningkat dalam pembelajaran membaca teks drama dengan baik dan benar. Seperti yang telah dipaparkan pada tabel dapat kita lihat peningkatan pembelajaran membaca teks drama mulai dari siklus 1 hingga siklus ke 2 terbukti terjadinya peningkatan yang mulanya nilai rata-rata hanya 74.2 menjadi 76.11

Pembelajaran membaca teks drama terlihat meningkat, setelah peneliti beserta guru melakukan pembelajaran dengan menggunakan metode quantum dan dengan metode tersebut meningkatkan gairah siswa dalam pembelajaran.

b. Pembahasan

Penelitian tindakan kelas (PTK) tentang pembelajaran membaca teks drama menggunakan lembar observasi pada siklus pertama terdapat 4 tahap yaitu: Perencanaan, pelaksanaan, pengamatan, refleksi. 
T. Nurullah, Aninditya Sri Nugraheni : Pembelajaran Membaca Teks Drama Dengan Menggunakan Metode Quantum di Kelas 5 MIN Pidie

Proses siklus I dilaksanakan pada Jumat 8 Januari 2021, ketika pelaksaan akan dimulai peneliti melakukan diskusi dengan wali kelas/guru yang bersangkutan untuk menggunakan metode quantum pada mata pelajaran Bahasa Indonesia yang mengenai tentang pembelajaran membaca teks drama adapun yang dipersiapkan oleh peneliti berupa RPP, Lembar observasi siswa, teks drama serta pedoman penilaian individu siswa.

Pelaksanaan pembelajaran siklus pertama berjalan dengan lancar, pembelajaran yangdilakukan mengikuti jalur RPP yang telah disediakan yang diawali dengan pendahuluan mencakup mengucap salam, mengecek kehadiran siswa, melaksanakan apersepsi, menjelaskan secara umum tentang materi dan metode yang akan di ajarakan. Pada kegiatan awal yang dilaksanakan guru mengikuti waktu sesuai dengan alokasi waktu yang ada pada RPP.

Pada saat kegiatan inti dilaksanakan guru memperkenalkan siswa bagaimana cara mengenal membaca teks drama dengan baik dan benar, dengan tujuan pembelajaran tersebut mudah difahami oleh peserta didik setelah itu guru memberikan ransangan kepada peserta didik dengan memberikan beberapa topiktopik tentang teks drama melalui metode quantum.

Selama proses pembelajaran membaca teks drama yang dilakukan dengan menggunakan metode quantum pada siklus I yang dihadiri oleh 20 siswa dengan persentase $83.33 \%$ jadi ada 4 siswa yang tidak menghadiri sekolah dengan persentase 16.66 dengan berbagai alasan, ada yang sakit, izin maupun tanpa keterangan. Hasil penilaian berpedoman pada penilaian membaca teks drama dan pada skala yang ditentukan. Adapun kriteria penilaian pada saat pembelajaran sebagai berikut: 1) Aspek kelancaran dengan rentang nilai 1-20, 2)Aspek Intonasi/vocal dengan rentang nilai 1-20, 3).Aspek Ketepatan penjedaan rentang nilai 1-15, 4). Aspek gaya/ekspresi dengan rentang nilai 1-15, 5). Aspek penguasaan karakter dengan rentang nilai 1-15, 6).Aspek penguasaan panggung dengan rentang nilai 1-15. 
T. Nurullah, Aninditya Sri Nugraheni : Pembelajaran Membaca Teks Drama Dengan Menggunakan Metode Quantum di Kelas 5 MIN Pidie

Refleksi yang dilakukan peneliti beserta guru kelas setelah melakukan penelitian pembelajaran membaca teks drama dengan metode quantum yaitu 1 . Kelebihan pada siklus 1 terjadinya peningkatan walaupun belum terlalu maksimal, 2. Siswa terlihat antusias dalam pembelajaran walaupun sebagian siswa pada saat membaca teks drama masih membaca seperti biasa, 3. Waktu yang digunakan masih kurang sehingga ketika menjelaskan tidak cukup waktu.

Setelah hasi penelitian siklus I diperoleh dan dibutuhkan beberapa perbaikan, maka peneliti melanjutkan dengan siklus ke II. Siklus ke II bertujuan untuk memperbaiki dan meningkatkan beberapa kendala yang diperoleh pada siklus I, demikian dengan adanya siklus II dapat terlaksana dengan baik untuk meningkatkan pembelajaran siswa dan kualitas pada proses pembelajaran yang dilaksanakan oleh guru.

Pelaksanaan siklus II terdapat peningkatan kehadiran siswa yang semulanya berjumlah 20 hingga menjadi 23 dengan persentase $95.83 \%$ dan yang tidak hadi menjadi menurun yang semulanya 4 siswa menjadi 1 siswa dengan persentase $4.16 \%$, peneliti dan guru mempersiapkan beberapa kebutuhan dalam melaksanakan pembelajaran membaca teks drama menggunakan metode quantum agar dapat terlaksana lebihh baik dan efesien. Hasil dari siklus I menjadi pedoman bagi peneliti dan guru untuk meningkatkan penelitian siklus II dengan cara diskusi dan menemukan langkah-langkah yang tepat sehingga dapat munculnya ide-ide terbaru pada saat menerapkan siklus II.

Peneliti dan guru mempersiapkan langkah-langkah penggunaan metode quantum dengan menyamakan persepsi lalu menyiapkan RPP, bahan pembelajaran, dan instrument penelitian. Pada saat awal kegiatan guru memberikan salam kepada siswa, lalu mengarahkan siswa untuk berdoa, mengabsensi siswa dan melakukan apersepsi dengan pembelajaran yang lalu dengan ceria agar siswa tidak tegang dalam pembelajaran.

Setelah kegiatan awal sukses dilaksanakan peneliti mengarahkan siswa menuju kegiatan inti pembelajaran yang diawali dengan menjelaskan tentang teks 
T. Nurullah, Aninditya Sri Nugraheni : Pembelajaran Membaca Teks Drama Dengan Menggunakan Metode Quantum di Kelas 5 MIN Pidie

drama dalam keadaan ceria, setelah menjelaskan peneliti mengarahkan siswa untuk membagi kelompok menjadi 4 kelompok yang dilakukan secara undian agar siswa mampu berinteraksi antara sesame teman.

Pada tahap selanjutnya guru membagikan teks drama yang telah disediakan kepada 4 kelompok yang sudah ditentukan, peneliti mengarahkan siswa untuk membaca teks drama dan mempelajari gaya, intonasi, penguasaan yang dibutuhkan dalam membaca teks drama, setelah diskusi berhasil dilaksanakan, peneliti meminta kepada tiap-tiap kelompok untuk menampilkan secara kelompok dan siswa lain mendengarkan adegan yang akan ditampilkan.

Refleksi yang dilakukan oleh peneliti dan guru pada saat siklus II terhadap pembelajaran yang telah dilaksanakan yaitu berupa: 1. Terjadinya peningkatan pembelajaran pada siklus keII 2. Siswa terlihat sangat antusias dan siswa terlihat sangat betah dalam mempelajari dan mempraktikkan drama yang telah disediakan oleh peneliti, 3. Siswa lebih percaya diri mempraktikkan drama dengan gayanya tersendiri, 4. Penggunaan metode pembelajaran quantum masih terdapat kelemahan, ada beberapa siswa masih ragu dan ketakutan pada saat tampil drama didepan kelas.

\section{KESIMPULAN}

Melalui kegiatan yang telah peneliti dan guru laksanakan, berdasarkan nilai yang diperoleh dari hasil penelitian terhadap kelas 5 MIN 6 Pidie pada siklus 1 yang dilaksanakan pada Jum'at, 08 Januari 2021diikuti oleh 20 siswa sehingga kehadiran siswa mencapai $83.33 \%$, begitu juga siswa yang tidak dapat hadir sebanyak 4 siswa, sehingga ketidak hadiran siswa mencapai $16.66 \%$. sedangkan nilai yang diperoleh dari hasil penelitian pada siklus 1, maka penelitian dilanjutkan dengan siklus ke 2 terhadap kelas 5 MIN 6 Pidie. Pada siklus ke 2 yang dilaksanakan pada Senin, 12 Januari 2021 yang diikuti oleh 23 siswa maka kehadiran siswa mulai meningkat menjadi 95.83\%, begitu juga siswa yang tidak dapat hadir sebanyak 1 siswa, sehingga ketidak hadiran siswa mencapai 4.16\%. Adapun Refleksi yang dilakukan peneliti beserta guru kelas setelah melakukan penelitian pembelajaran membaca teks drama dengan metode quantum yaitu 1 . 
T. Nurullah, Aninditya Sri Nugraheni : Pembelajaran Membaca Teks Drama Dengan Menggunakan Metode Quantum di Kelas 5 MIN Pidie

Kelebihan pada siklus 1 terjadinya peningkatan walaupun belum terlalu maksimal, 2. Siswa terlihat antusias dalam pembelajaran walaupun sebagian siswa pada saat membaca teks drama masih membaca seperti biasa, 3. Waktu yang digunakan masih kurang sehingga ketika menjelaskan tidak cukup waktu, sedangkan Refleksi yang dilakukan oleh peneliti dan guru pada saat siklus II terhadap pembelajaran yang telah dilaksanakan yaitu berupa: 1. Terjadinya peningkatan pembelajaran pada siklus keII 2. Siswa terlihat sangat antusias dan siswa terlihat sangat betah dalam mempelajari dan mempraktikkan drama yang telah disediakan oleh peneliti, 3. Siswa lebih percaya diri mempraktikkan drama dengan gayanya tersendiri, 4. Penggunaan metode pembelajaran quantum masih terdapat kelemahan, ada beberapa siswa masih ragu dan ketakutan pada saat tampil drama didepan kelas

\section{E. SARAN DAN REKOMENDASI}

Penelitian pembelajaran membaca teks drama yang dilakukan oleh peneliti ini masih jauh dari kata sempurna karena masih banyak dan sangat kurang dalam penelitian maupun tulisan yang telah ditulis, Adapun saran peneliti kepada guru agar dalam pembelajaran mestinya menggunakan metode yang sesuai dengan pembelajaran yang di ajarkan, saran peneliti Pembina sekolah yaitu mengajarkan macam-macam metode pembelajaran yang telah ditetapkan oleh pemerintah, sehingga guru mampu mengajarkan siswa dengan mudah. Peneliti juga merekomendasikan metode quantum dalam pembelajaran Bahasa Indonesia sangatlah penting dang sangat mudah digunakan ketika pembelajaran.

\section{UCAPAN TERIMAKASIH}

Peneliti mengucapkan terimakasih banyak kepada kepala madrasah MIN 6 Pidie yang telah memberikan izin bagi peneliti untuk meneliti siswa kelas 5, begitu juga terimakasih peneliti ucapkan atas antusiasnya siswa kelas 5 dalam penelitian yang dilakukan dann tidak lupa beribu terimakasih peneliti ucapkan kepada guru kelas 5 yang telah membimbing peneliti mulai dari siklus I hingga siklus II tanpa pambrih sedikitpun hingga terselesainya penelitian ini. 
T. Nurullah, Aninditya Sri Nugraheni : Pembelajaran Membaca Teks Drama Dengan Menggunakan Metode Quantum di Kelas 5 MIN Pidie

\section{DAFTAR PUSTAKA}

Nawawi, I. 2009. Analisis Strategi Advokasi teori dan Evaluasi. Surabaya

DePorter, Bobbi. Quantum Learning : Membiasakan Belajar Nyaman Dan Menyenangkan. Kaifa, 2005.

Ina. "20 Macam Macam Metode Pembelajaran Lengkap." DosenPsikologi.com, 7 Juli 2017. https://dosenpsikologi.com/macam-macam-metodepembelajaran.

Isjoni. Cooperative Learning: Efektifitas Pembelajaran Kelompok. Bandung: Alfabeta, 2012.

Kuraesin, Imas Nenden, Nana Suryana, dan Nita Anjung Munggaran. "Meningkatkan Minat Baca Peserta Didik Melalui Metode Quantum Reading Dalam Mata Pelajaran Bahasa Indonesia." Madrosatuna: Jurnal Pendidikan Guru Madrasah Ibtidaiyah 2, no. 1 (4 Juli 2019): 42-50. https://doi.org/10.47971/mjpgmi.v2i1.65.

Nurfauzan, Prayogi. "Pengaruh Model Quantum Learning Terhadap Penguasaan Teknik Dasar Lompat Jauh Siswa Pada Pembelajaran Atletik Di Sekolah Dasar." JMIE (Journal of Madrasah Ibtidaiyah Education) 2, no. 2 (30 November 2018): 254-64. https://doi.org/10.32934/jmie.v2i2.77.

"penilaian metode quantum dalam membaca teks - Penelusuran Google." Diakses 17

Januari 2021. https://www.google.com/search?q=penilaian+metode+quantum+dalam+m embaca+teks\&oq=penilaian+metode+quantum+dalam+membaca+teks\&a $\mathrm{qs}=$ chrome..69i57.20463j1j7\&sourceid=chrome \&ie $=U T F-8$.

Priatiningsih, Esti. "Peningkatan Keterampilan Membaca Teks Melalui Metode Bermain Peran Di Kelas II Sekolah Dasar Negeri Jatisawit 02 Kecamatan Bumiayu Kabupaten Brebes Tahun Pelajaran 2020/2021.” Majalah Lontar 32, no. 2 (28 November 2020): 36-48. https://doi.org/10.26877/ltr.v32i2.7294.

Safitri, Darna, Laurensius Salem, dan Deden Ramdani. "Peningkatan Keterampilan Membaca Teks Drama Menggunakan Metode Jigsaw Di Smp.” Jurnal Pendidikan Dan Pembelajaran Khatulistiwa 4, no. 11 (16 November 2015). https://jurnal.untan.ac.id/index.php/jpdpb/article/view/12390.

Savitra, Khanza. "12 Peran Guru Dalam Proses Pembelajaran." DosenPsikologi.com, $13 \quad$ September 2017. https://dosenpsikologi.com/peran-guru-dalam-proses-pembelajaran.

Sudarman, Satrio Wicaksono, dan Ira Vahlia. "Efektifitas Penggunaan Metode Pembelajaran Quantum Learning Terhadap Kemampuan Pemahaman Konsep Matematis Mahasiswa." Al-Jabar : Jurnal Pendidikan Matematika 7, no. 2 (20 Desember 2016): 275-82. https://doi.org/10.24042/ajpm.v7i2.42. 
T. Nurullah, Aninditya Sri Nugraheni : Pembelajaran Membaca Teks Drama Dengan Menggunakan Metode Quantum di Kelas 5 MIN Pidie

Zulfa Khairunnosa, Nadea, dan R Rachmy Diana. "Pengaruh Pelatihan Quantum Learning Terhadap Minat Belajar Ilmu Pengetahuan Alam Pada Siswa Sekolah Dasar." Jurnal Intervensi Psikologi (JIP) 10, no. 2 (25 Desember 2018): 73-82. https://doi.org/10.20885/intervensipsikologi.vol10.iss2.art1.

Al-Madrasah: Jurnal Ilmiah Pendidikan Madrasah Ibtidaiyah Vol. 5, No. 2, Januari-Juni 2021 